\title{
The Transatlantic Trade and Investment Partnership: Trojan horse or positive force for health?
}

\author{
Marine Faure and Brian Ward
}

Affiliation: European Respiratory Society, EU affairs, Brussels, Belgium.

Correspondence: Marine Faure, European Respiratory Society, EU affairs, Brussels, Belgium. E-mail: Marine.Fauredersnet.org for health? http://ow.ly/NOVdp

For centuries, Greek mythology strove to reflect human behaviour through its myths. One of the more well-known myths is that of the Trojan horse, a poisoned chalice offered to the Trojans in which the Greeks were hidden to invade the city, and which has come to symbolise human deceit. Today, this link between the myth and actual facts is in the limelight with respect to the Transatlantic Trade and Investment Partnership (TTIP), which is currently being negotiated between the European Union (EU) and the USA. Some see the EU citizens as the trapped Trojans and the EU and the USA leaders as the cunning Greeks. Roughly speaking, the TTIP aims at removing trade barriers (tariffs, unnecessary regulations and restrictions on investments etc.) in a wide range of economic sectors including health. The purpose is to facilitate the purchase and sale of goods and services between the EU and the USA, as well as to facilitate the investment of companies [1]. On the one hand, proponents guarantee that the treaty will be the opportunity to create growth and employment and promote healthcare in a Eurozone still struggling [2]. On the other hand, opponents argue it could lower the health protection standards of Europeans and challenge the right of the EU to regulate. While the public debate remains heated, it is crucial to consider both sides in order to understand the potential benefits and risks from the TTIP for the European health community. This piece aims to set out the most controversial elements and how they may impact on the health care system.

\section{Efficient mutual recognition and harmonisation or the lowering of European} standards?

Mutual recognition and harmonisation of technical regulation, standards and norms are important elements of the TTIP. Proponents of the TTIP believe this could have positive consequences on inspection of pharmaceutical companies' facilities and enhance the cooperation regarding clinical trials. Opponents raise concerns about strict European health standards that could be lowered by recognising and adopting less comprehensive USA standards. In the public debate, this fear has been driven by the potential import of hormone-treated beef, chlorine-washed chicken or unlabelled genetically modified organisms (GMOs), which are all currently forbidden in the EU.

It is expected that the TTIP will lay the foundations for an increased cooperation for advanced medicines between the European Medicines Agency and the Food and Drugs Administration for the benefits of patients. Currently, European and USA authorities proceed with inspections of companies' facilities on their territory and third countries in order to check compliance with Good Manufacturing Practices and verify the quality of medical products [3]. A greater cooperation could reduce avoidable duplications and "pave the way for the development of global standards" [4]. In addition, further harmonisation of technical requirements with regards to clinical trials could make it easier to share clinical trials data conducted on

Received: April 162015 | Accepted after revision: May 032015

Conflict of interest: Marine Faure and Brian Ward are employees of the European Respiratory Society.

Copyright OERS 2015 
both sides of the Atlantic. As a result, Small and Medium-sized Enterprises would benefit from lower transaction costs and patients from quicker access to the market of innovative medicines or treatment.

Regarding the belief that health standards will be compromised within the TTIP, it seems unlikely that the EU wishes to renegotiate its own legislation with the USA. The European Commission underlined that "basic laws, like those relating to GMOs or which are there to protect human life and health, animal health and welfare, or environment and consumer interests will not be part of the negotiations" [5]. Similarly, the Atlantic Community, a foreign policy think tank, recalled that the objective of mutual recognition and harmonisation is not to adopt the lowest common denominator, but rather to allow negotiators and consumers to see where they differ unnecessarily [6]. There is evidence from the Free Trade Agreement between the EU and Canada (CETA), which is considered similar to the TTIP in many ways, that existing EU health standards can be preserved. In a deep analysis of the European parliament on CETA [7], it is mentioned that the treaty will not affect the EU's import ban on hormone-treated beef or chlorine-washed chicken and the same type of protection is expected to be true for the TTIP.

The safeguard of standards should also apply to the rules of transparency imposed through the new EU regulation on clinical trials. Concerns have been raised following the circulation of a leaked pharmaceutical industry wish list, calling for a limited disclosure of clinical trials data in the TTIP [8]. This could be achieved by adopting USA standards or by the inclusion of the trade secret protection directive in the TTIP [9], currently being negotiated in the EU. In the pushback against this wish-list Biljana Borzan, Member of the European Parliament (MEP), recalled, in a written question, that reducing access to clinical trials data could lead to "poor treatment decisions, missed opportunities for evidence-based medicines and the repetition of trials" [10]. However, it is unlikely that the EU would undermine its own, recently adopted, regulation.

\section{A boost to innovative medicines or an increase in pricing?}

Since the beginning of the negotiations in 2013, the European Commission has made clear that intellectual property rights (IPR) would be included in TTIP [11]. On one side, supporters highlight that greater alignment and the establishment of common standards between the EU and the US IPR could boost research and innovation for medicines development [12]. On the other side, concerns have been raised regarding the inclusion of provisions, which could ultimately increase the price of medicines.

What can be expected is that common IPR standards would give an incentive to invest in both the development and research of new medicines [13]. As the European Federation of Pharmaceutical Industries and Associations noted "without IPR, some of the most important medical breakthroughs would not have been possible, neither would generic medicines be on the market" [14].

However, it is true that the leaked wish-list of the pharmaceutical industry mentioned worrying provisions with regards to generics. Firstly, it called for extended patent terms of medicines and an increase of data exclusivity for biological medicinal products [15]. If included, as the USA already proposed in the Trans-Pacific partnership [4], it could prolong the market exclusivity for the originator firm and delay the introduction of generics into the market. Secondly, the wish-list mentioned the inclusion of a pharma annex that would "promote transparency principles in processes and reward innovation" [15]. According to the Common Network, a civil society initiative working at the EU level, the industry seeks here to set up higher prices for medicines and more insight into the pricing and reimbursement policies, currently established by Member States [8].

Having said this, it must be emphasised that these sets of provisions have never been mentioned in the European Commission statements on the TTIP, but only in the pharmaceutical wish-list. Accordingly, there can only be assumptions but no current evidence of an increase of pricing in the future treaty.

\section{An appropriate foreign investors protection or a threat to the ability of the EU to regulate in the health policy sphere?}

Among all the issues in the TTIP, the investor-state dispute settlement (ISDS) is undoubtedly the most controversial. ISDS is a mechanism that allows foreign investors to sue states hosting their investment, in international arbitration courts, if they believe that government acts incur losses for their brand. This means that if a government was to expropriate an investor or to introduce legislation that discriminates against its products, the government could be sued for compensation [16]. ISDS proponents say that it would create a positive climate for investors encouraging USA investment into the EU markets and vice versa [15]. Moreover, besides the solidity of the EU and the USA court systems, they argue that investors still come across problems affecting their investments, which their domestic court systems are not always able to deal with effectively [17]. Opponents claim that ISDS could undermine the sovereign right of the EU and its Member States to regulate on public health, by allowing foreign investors to challenge European or national laws.

No evidence has been found that ISDS could attract foreign investment. By contrast, past events have shown that the mechanism has a worrying effect on the ability of governments to regulate on health. In 2010 and in 


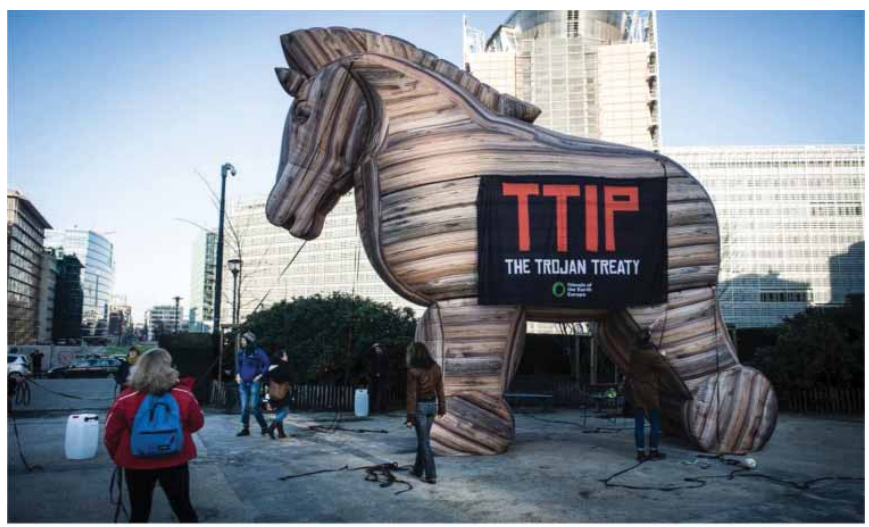

FIGURE 1 A giant Trojan horse set up by Friends of the Earth in front of the European Commission to protest against the Transatlantic Trade and Investment Partnership (TTIP) agreement. Reproduced with permission from W. Dabkowski.

2011, Philip Morris brought the lawsuit respectively against Uruguay and Australia over laws enforcing plain packaging on cigarettes, via an ISDS mechanism in their respective free-trade agreements [17]. These cases are still ongoing but they have already caused chilling effects [4]. In 2013, New Zealand explicitly announced that it will postpone plain packaging legislation until the Australian case is resolved [18]. Given the public [19] and political [20] contestation of ISDS, the current EU Trade commissioner, Cecilia Malmström, made a few proposals to reform the mechanism. For example, the treaty could include guarantees for governments to regulate on health, as well as a clause recalling that the change in a legal regime cannot be a reason to sue a state. Notwithstanding, these statements, it seems that ISDS carries more risks than benefits for the European health community. According to the MEP Bart Staes, Health Committee rapporteur of the European Parliament on the TTIP, it should not be included in the final agreement, even with amendments [21]. MEPs from the same committee recently shared his view by rejecting the mechanism with a majority voting against [22].

\section{The spread of publicly run health services or an improvement of the healthcare system?}

The question on the mind of many is whether the national health services will be impacted by the TTIP. On the one hand, some argue that including healthcare services in the TTIP would be a good opportunity to enjoy affordable and high-quality healthcare in Europe [12]. On the other hand, people fear that it would open up publicly run health services to competition from private sector healthcare providers, as well as preventing governments from bringing previously privatised health into the public sector [4]. The European Commission has made several statements saying that health services would be excluded from the TTIP [4]. Furthermore, a recent joint statement signed by Cecilia Malmström and the USA trade representative, Michael Froman, recalled that the TTIP will not prevent governments from providing or supporting health services as they wish [23]. These assurances are also confirmed by a leaked draft brought to light by the BBC on what the Member States would specifically like to include or exclude from the agreement. It is mentioned that "the EU reserves the right to adopt or maintain any measures with regard to the provision of all health services which receive public funding or State support in any form" [24]. Member States were also able to make their own restrictions on which of the privately funded services they would or would not include in the TTIP. It can, therefore, be assumed that health services can only be affected by the TTIP if Member States want them to be [24].

\section{Conclusion}

It would appear that the TTIP is neither a Trojan horse, nor a goose that lays golden eggs. On the one hand, it could help to accelerate the global development of medicines, spur innovation and enhance timely patient access to innovative treatments. On the other hand, the EU needs to make sure that those benefits will not come at the expense of the affordability of medicines and the ability of Member States to manage public health policy.

What is certain is that trade agreements are an inevitable part of the modern and liberal democratic system. Europe's leaders, led by the European Commission see, in the TTIP, the opportunity to boost economic growth and are charging ahead at full tilt to sign the agreement, only time will tell whether or not they have backed the wrong horse for health.

\section{References}

1 European Commission. European Commission - Fact Sheet: report on the online consultation on investment protection and investor-to-state dispute settlement in the Transatlantic Trade and Investment Partnership Agreement. http://europa.eu/rapid/press-release_MEMO-15-3202_en.htm Date last accessed: March 30, 2015. Date last updated: January 13, 2015.

2 Dullien S, Garcia A, Janning J. A Fresh Start for TTIP. London, European Council for Foreign Relations (ECFR), 2015. Available from: www.ecfr.eu/page/-/ECFR124_-_TTIP.pdf 
3 Goyens M. How will TTIP affect the health of the Europeans? www.beuc.eu/blog/how-will-ttip-affect-the-healthof-europeans/ Date last accessed: March 30, 2015. Date last updated: September 11, 2014.

4 Khan U, Pallot, R, Taylor D, et al. The Transatlantic Trade and Investment Partnership: International Trade Law, Health Systems and Public Health. London, London School of Economics (LSE), 2015. Available from: http://eprints. lse.ac.uk/60945/1/_lse.ac.uk_storage_LIBRARY_Secondary_libfile_shared_repository_Content_Kanavos\%2C\%20P_ The\%20TTIP\%20International\%20Trade\%20Law_2015.pdf

5 European Commission. Questions and answers: about TTIP - basics, benefits, concerns. http://ec.europa.eu/trade/ policy/in-focus/ttip/about-ttip/questions-and-answers/index_en.htm Date last accessed: March 30, 2015. Date last updated: March 19, 2015.

6 Schmucker C. Why regulatory harmonisation will not equal regulatory erosion. www.atlantic-community.org//why-regulatory-harmonization-will-not-equal-regulatory-erosion Date late accessed: March 30, 2015. Date last updated November 10, 2015.

7 Bierbrauer E. In-Depth Analysis: Negotiations on the EU-Canada Comprehensive Economic and Trade Agreement (CETA) Concluded. Policy Department, Directorate-General For External Policies, 2014. Available from: http://www.europarl.europa.eu/RegData/etudes/IDAN/2014/536410/EXPO_IDA(2014)536410_EN.pdf

8 The Transatlantic Trade and Investment Partnership-TTIP: A Civil Society Response to the Big Pharma Wish List. Brussels/Berlin, Joint Position, 2014. Available from: http://www.prescrire.org/Docu/DOCSEUROPE/20140324Civil SocietyResponseBigPharmaWishList_final.pdf

9 Joint Statement. EU Trade Secrets Directive Threat to Health, Environment, Free Speech and Worker Mobility: Multi-Sectoral NGO Coalition Calls for Greater Protections for Consumers, Journalists, Whistleblowers, Researchers and Workers. Available from: http://www.epha.org/IMG/pdf/Statement__EU_Trade_Secrets_Directive_Needs_ Amendments.pdf

10 Borzan B. Parliamentary question: transatlantic trade and investment partnership (TTIP) and clinical trials. www.europarl.europa.eu/sides/getDoc.do?type=WQ\&reference=E-2015-002413\&format=XML\&language=EN Date late accessed: March 30 2015. Date last updated: February 13, 2015.

11 European Commission. Member States endorse EU-US trade and investment negotiations. http://europa.eu/rapid/ press-release_MEMO-13-564_en.htm Date late accessed: March 30, 2015. Date last updated: June 14, 2013.

12 Erixon F, Ferracane F. M, Van der Marel E. ECIPE Occasional Paper 02/2015. The Health of Nations: A Transatlantic Trade and Investment Agenda for Better Healthcare. European Centre for International Political Economy (ECIPE), 2015. Available from: http://www.ecipe.org/app/uploads/2015/03/ECIPE-TTIP-Health-Occasional-paper.pdf

13 Lillypad EU. The EU-US Transatlantic Trade and Investment Partnership (TTIP). Eli Lilly, 2013. Available from: https://lillypad.eu/EUPA_B_2013_02_Lilly_TTIP_Brochure\%20A4_4.pdf

14 European Federation of Pharmaceutical Industries and Associations (EPFIA). TTIP and Healthcare: Separating Facts from Fiction. Brussels, EPFIA, 2015. Available from: www.efpia.eu/uploads/TTIP_Myths_Facts.pdf

15 Weiss M. Trading Health? UK Faculty of Public Health Policy Report on the Transatlantic Trade and Investment Partnership. London, UK Faculty of Public, 2015. Available from: http://www.fph.org.uk/uploads/FPH\%20Policy\% 20report\%20on\%20the\%20Transatlantic\%20Trade\%20and\%20Investment\%20Report\%20-\%20FINAL.pdf

16 Körnig J, Schmucker C. TTIP: a chance for Europe: the criticism on TTIP is widespread but is it justified? Explanations of central issues. https://gap.org/en/think-tank/publications/five-questions/ttip-chance-europe Date last accessed: March 30, 2015. Date last updated: May 22, 2014.

17 Porterfield MC, Byrnes CR. Philip Morris v. Uruguay: Will investor-State arbitration send restrictions on tobacco marketing up in smoke? www.iisd.org/itn/2011/07/12/philip-morris-v-uruguay-will-investor-state-arbitration-sendrestrictions-on-tobacco-marketing-up-in-smoke/ Date last accessed: May 21, 2015. Date last updated: July 12, 2011.

18 Turia T. Government moves forward with plain packaging of tobacco products. http://www.beehive.govt.nz/release/ government-moves-forward-plain-packaging-tobacco-products Date late accessed: March 30, 2015. Date last updated: February 19, 2013.

19 European Commission. Report presented today: consultation on investment protection in EU-US trade talks. http://trade.ec.europa.eu/doclib/press/index.cfm?id=1234 Date last updated: January 13, 2015. Date last accessed: March 30, 2015.

20 Euractiv. Parliament's opposition to TTIP arbitration on the rise. www.euractiv.com/sections/trade-society/parliamentsopposition-ttip-arbitration-rise-313935 Date last accessed: May 21, 2015. Date last updated: April 27, 2015.

21 Staes B. Draft Opinion of the Committee on the Environment, Public Health and Food Safety for the Committee on International Trade on recommendations to the European Commission on the negotiations for the Transatlantic Trade and Investment Partnership (TTIP) (2014/2228(INI)). Brussels, European Parliament, 2014. Available from: http://www.europarl.europa.eu/sides/getDoc.do?pubRef=-\%2F\%2FEP\%2F\%2FNONSGML\%2BCOM PARL\%2BPE-544.393\%2B01\%2BDOC\%2BPDF\%2BV0\%2F\%2FEN

22 Euractiv. MEPs want health excluded from TTIP talks. http://www.euractiv.com/sections/health-consumers/ meps-want-health-excluded-ttip-talks-313769 Date last updated: April 15, 2015. Date late accessed: April 15, 2015.

23 Transatlantic trade and investment partnership. Joint Statement on Public Services. http://trade.ec.europa.eu/ doclib/docs/2015/march/tradoc_153264.pdf Date last updated: March 20, 2015. Date late accessed: April 15, 2015.

24 Campbell G. TTIP: Transatlantic deal text leaked to BBC. http://www.bbc.com/news/uk-scotland-scotland-politics31631461 Date late accessed: March 30, 2015. Date last updated: February 26, 2015. 